у 1722 р. Харківський колегіум. Особливістю навчальних закладів на Слобідській Україні був громадський характер їх функціонування, переважання виховного та розвивального аспектів порівняно з освітнім, широкий розвій шкіл, що сприяло високому рівню грамотності населення.

3 другої половини XVIII ст., відповідно до імперської політики, освіта будується за становою ознакою. На Слобідській Україні виникають приватні пансіони закритого типу, призначені для навчання дітей дворянства. Харківський колегіум поступово втрачає роль загальноосвітнього закладу, у якому навчалися представники різних станів і перетворюється на духовну семінарію.

Подальшого дослідження потребує аналіз політики російського уряду щодо розвитку освіти на Слобідській Україні у XVII-XVIII ст.

\title{
Література
}

1. Багалій Д. Історія Слобідської України / Д. Багалій. - Харків : Дельта, 1993. 256 с. 2. Держархів Сумської області, ф. 749, оп. 1, спр. 32, 242 арк. 3. Держархів Сумської області, ф. 804, оп. 1, спр. 2, 12 арк. 4. Держархів Сумської області, ф. 804, оп.1, спр. 10, 2 арк. 5. Держархів Сумської області, ф. 804, оп.1, спр. 11, 2 арк. 6. Держархів Сумської області, ф. 804, оп.1, спр. 16, 2 арк. 7. Держархів Сумської області, ф. 804, оп. 1, спр. 25, 2 арк. 8. Держархів Сумської області, ф. 960, оп.1, спр. 21, 74 арк. 9. Держархів Сумської області, ф. 1173, оп. 1, спр. 8, 28 арк. 10. Посохова Л. Ю. На перехресті культур, традицій, епох: православні колегіуми України наприкінці XVII - на початку XIX ст. : [монографія]/ Л. Ю. Посохова. - Харків : ХНУ ім. В.Н. Каразіна, 2011. - 399 с. 11. Сумщина в історії України : [навч. посіб.]. - Суми : МакДен, 2005. - 496 с. 12. Танцюра В. І. Історія Слобідської України: [навч. посіб.] / В. І. Танцюра, О.О.Пересада. - Харків : ХНУ імені В. Н. Каразіна, 2013. - 368 с. 13. Тесля М. П. Олександр Олександрович Паліцин і його послідовники / М. Тесля. - Суми : МакДен, 2010. - 480 с.

Свгеній Свтушенко

\section{РОЗВИТОК ЗМІСТУ ТА СТРУКТУРИ ФІЗИЧНОГО ВИХОВАННЯ У ВИЩИХ ПЕДАГОГІЧНИХ НАВЧАЛЬНИХ ЗАКЛАДАХ УКРАЇНИ У 1944-1991 рр.}

Євтушенко С. Г. Розвиток змісту та структури фізичного виховання у вищих педагогічних навчальних закладах України у 1944-1991 pp.

У процесі аналізу встановлено, що основними носіями змісту та структури фізичного виховання студентів ВНЗ були навчальні плани і програми єдиного державного зразка. У програмах зміст фізичного виховання диференціювався за спрямуванням, компонентами, рівнем підготовки студентів. 3'ясовано, що протягом досліджуваного періоду до структури фізичного виховання студентів вищих навчальних закладів входили два види занять: обов'язковий та факультативний курси.

Ключові слова: фізичне виховання студентів, вищі педагогічні навчальні заклади, зміст та структура фізичного виховання.

Евтушенко Е. Г. Развитие содержания и структуры физического воспитания в высших педагогических учебных заведениях Украины в 1944-1991 гг.

В процессе анализа установлено, что основными носителями содержания и структуры физического воспитания студентов вузов были учебные планы и программы единого 
государственного образца. В программах содержание физического воспитания дифференцировалось за направленностью, компонентами, уровнем подготовки студентов. Выяснено, что в течение исследуемого периода в структуру физического воспитания студентов высших учебных заведений входили два вида занятий: обязательный и факультативный курсы.

Ключевые слова: физическое воспитание студентов, высшие педагогические учебные заведения, содержание и структура физического воспитания.

Yevtushenko Ye. G. Content and structure development of physical education at teacher training universities of Ukraine in 1944-1991.

This article analyzes content and structure development of physical education at teacher training universities of Ukraine in 1944-1991. It was proved that the main carriers of content and structure of physical education of university students were curricula and programs of common state standard. Updating programs and curricula that influenced content and structure development of physical education significantly, held in 1948, 1953, 1956, 1963, 1975, 1987 and 1989. In the programs the content of physical education was differentiated by orientation (general physical development; sports improvement; educational and health-improving, vocational and applied physical training), components (theoretical knowledge, practical skills), the level of students' training (preparatory, specialized and sports department). It was found that during the study period major changes in the content were related to its direction. By the end of the 1940s general physical development was a priority, from 1950 till mid-1980s it was sport improvement, from 1987 to 1991 it was educational and health-improving, vocational and applied physical training of students. The structure of the physical education of university students included two kinds of activities: compulsory and optional courses. The curriculum set amount of hours that was set aside for studying these courses. During the study period there were certain volume adjustments depending on changes in the content of physical education.

Key words: students' physical education, teacher training universities, content and structure of physical education.

Проблеми відбору найбільш ефективних рухових дій задля розвитку фізичних якостей молоді, їх дозування та структурування постійно перебувають в центрі уваги науковців, педагогів, громадськості. Вочевидь сучасне реформування змісту та структури фізичного виховання не може досягнути бажаного без урахування тих провідних ідей, які були перевірені часом і давали позитивний результат. Здобутки попередніх часів є не лише важливим джерелом збагачення фактами й теоретичними положеннями, але й роблять можливим прогнозування фізичного розвитку молоді за умов певної змістової та структурної побудови навчального процесу.

Аналіз історико-педагогічної літератури свідчить, що різні аспекти фізичного виховання студентської молоді у вищих навчальних закладах розкривалися у дослідженнях I. Адамової, М. Бєляєва, Н. Боляк, Б. Ведмеденка, П. Гиренка, М. Ісаєвої, О. Куц, О. Ледовського, К. Михайлова та ін. Особливості професійної спрямованості фізичного виховання майбутніх учителів вивчалися М. Виленським, Л. Вишневою, Б. Грицюком, С. Домбровським, Р. Скульським та ін. Питання концептуальних змін у системі фізичного виховання висвітлювалися у працях Ю. Івасюти, В. Язловецького та ін.

Проте, огляд літератури надає підстави вважати, що спеціальних досліджень, присвячених розвитку змісту та структури фізичного виховання у вищих педагогічних 
навчальних закладах, не проводилося.

Meта статmі- на основі аналізу навчальних планів та програм дослідити особливості розвитку змісту та структури фізичного виховання у вищих педагогічних навчальних закладах протягом 1944-1991 pp.

Основними носіями змісту та структури фізичного виховання у педагогічних ВН3 були навчальні плани і програми. Перша загальнодержавна програма 3 фізичного виховання для ВНЗ була затверджена у 1937 р. Вона складалася з двох змістових компонентів: теоретичного і практичного. Теоретична підготовка передбачала засвоєння знань 3 історії фізичного виховання, самоконтролю, санітарно-гігієнічних вимог. Практична частина присвячувалася оволодінню основами гімнастики, легкої атлетики, лижного спорту, плавання, спортивних ігор. Програма будувалася відповідно до комплексу ГПО (готовий до праці і оборони). За своїм спрямуванням зміст цієї програми був орієнтований передовсім на загальнофізичну та військову підготовку молоді.

Програма передбачала таку структуру фізичного виховання: обов'язкові навчання на перших трьох курсах та факультативні заняття на четвертому курсі. Згідно з навчальним планом обов'язкові навчання проводилися в обсязі 2 год. на тиждень та вносилися до розкладу академічних занять. Факультативні заняття не входили до розкладу, на них відводилося 60 год. (2 год. на тиждень).

Програма 1937 р. діяла до кінця 1940-х рр. У 1948 р. набула чинності спеціальна програма з фізичного виховання для педагогічних інститутів. У ній, незважаючи на те, що основою залишався комплекс ГПО, військова підготовка поступово відходить на другий план. Акцент робився на загальнофізичний розвиток, набагато більше уваги відводилося спорту. На спортивне вдосконалення передовсім були зорієнтовані факультативні курси. Вони організовувалися у всіх ВНЗ і велися за такими видами спорту: гімнастика, легка атлетика, баскетбол, плавання, лижний спорт. Організація факультативних курсів за іншими видами спорту була можливою лише за спеціальним дозволом Міністерства вищої освіти СРСР [1, с. 2]. Програмою передбачалося збільшення обсягу годин фізичного виховання за рахунок факультативу. Згідно з навчальним планом на першому та другому роках навчання на факультатив відводилося по 2 год. на тиждень; у наступні роки - по 4 год.

Але вже на початку 1950-х pр. набуває чинності нова програма для студентів педагогічних ВНЗ. У ній були відображені більш високі вимоги до загальнофізичної та спортивної підготовки. Так, студенти, які завершували навчання на другому курсі мали обов'язково скласти усі норми ГПО II ступеня, а ті студенти, що займалися у спортивних секціях - виконати нормативи III спортивного розряду. У програмі чітко фіксувалося поєднання загальнофізичної і спортивної підготовки. На загальнофізичну підготовку був зорієнтований обов'язковий курс, а факультативний курс- на спортивне вдосконалення студентів.

Окрім того, передбачався поділ змісту фізичного виховання за рівнем фізичного розвитку студентів. Згідно 3 програмою практичні заняття проводилися за такими навчальними відділеннями: спеціальним, підготовчим та спортивного вдосконалення. Це давало можливість вивести в окрему групу найбільш обдарованих до спорту студентів та забезпечити їм повноцінне тренування.

Структурна побудова фізичного виховання відповідно до навчального плану для педагогічних ВНЗ складалася 3 двох видів занять: обов'язкового курсу загальної фізичної підготовки (180 годин на першому та другому курсах педагогічних інститутів і 100 годин на першому та другому курсах учительських інститутів) та факультативного курсу спортивного 
вдосконалення (2 години на тиждень на першому і другому курсах та 4 години на третьому $\mathrm{i}$ четвертому курсах) [2, с. 6].

Щоб оптимізувати структуру фізичного виховання і домогтися максимального виконання програми, у педагогічних ВНЗ проводилися зміни в навчальних планах. Ураховуючи, що завдання загальної фізичної підготовки мали розв'язуватися школою, зменшувався обсяг обов'язкового курсу. Аргументом на користь скорочення годин на цей курс було і те, що завантаження спортивних споруд обов'язковими заняттями заважали роботі спортивних секцій [2, с. 6]. Отже, зміни навчального плану були орієнтовані на покращення умов для розвитку спорту серед студентів. Для посилення контролю за рівнем спортивної підготовки студентів педагогічних інститутів Міністерство освіти УРСР рекомендувало проводити залік із факультативного курсу спортивного вдосконалення для третіх і четвертих курсів у 7 семестрі за вимогами III розряду 3 обраного виду спорту [3, с. 64].

У 1956 р. було затверджено нову редакцію попередньої програми під назвою «Обов'язковий курс фізичної підготовки за комплексом «Готовий до праці та оборони СРСР». У ній було підтверджено спортивну спрямованість змісту фізичного виховання студентів. Зокрема, уводилася спортивна спеціалізація за такими видами: легка атлетика (для всіх ВНЗ), лижний спорт, гімнастика, плавання, велоспорт, спортивні ігри та за іншими, залежно від умов навчальних закладів. Міністерство вищої освіти УРСР дозволяло замінювати курс загальної фізичної підготовки спеціалізацією за видами спорту. Наприклад, у Горлівському педагогічному інституті іноземних мов основною спеціалізацією було обрано баскетбол [5, с. 31]. У Сумському педагогічному інституті групи спортивного вдосконалення мали таку чисельність: спортивна гімнастика - 30 чол., легка атлетика - 18, волейбол - 40, баскетбол - 25, велосипедний та лижний спорт - 25, фехтування - 10, настільний теніс 20 [6, с. 26]. Як свідчили звіти педагогічних інститутів, спортивна спеціалізація навчальних груп сприяла покращенню якості спортивної підготовки студентів і поліпшенню спортивномасової роботи.

Фізичне виховання на першому та другому курсах факультету підготовки учителів 1-4 класів через відсутність спеціальної навчальної програми проводилася за програмою фізичного виховання педагогічних училищ на базі середньої освіти [5, с. 1].

На факультетах педагогічних інститутів погодинний обсяг викладання фізичного виховання різнився залежно від навчального плану дисципліни. Наприклад, на спеціальності «Іноземна мова та вихователь школи-інтернату» фізичне виховання викладалося протягом 14 семестрів у обсязі 130 год. із них: 30 год. відводилося на лекції і 100 - на практичні заняття. Обсяг щотижневих занять дорівнював 2 год. У 2 та 4 семестрі 3 цього предмета були заплановані заліки. 31 по 6 семестр в обсязі 200 год. як факультативна дисципліна викладалося «Спортивне вдосконалення» [4, с. 95]. На спеціальності «Українська мова та література» на фізичне виховання у 1-4 семестрі відводилося 140 год., усі вони проходили у формі практичних занять. Протягом 1, 2 та 3 семестрів обсяг навчального навантаження складав 2 год. на тиждень, а в 4 семестрі - 3. У 2 та 4 семестрі 3 цього предмета були заплановані заліки. 33 по 6 семестр в обсязі 140 год. як факультативна дисципліна викладалося «Спортивне вдосконалення» [4, с. 88].

Чергова програма з фізичного виховання студентів вишів була затверджена у 1963 р. У ній зберігався курс на спортизацію фізичного розвитку студентів. Для цього основними засобами фізичного виховання проголошувалися такі види спорту: гімнастика, легка атлетика, лижний спорт, плавання, баскетбол, волейбол. Зміст фізичного виховання 
передбачав оволодіння руховими діями, властивими цим видам спорту. Вимоги програми пов'язувалися вже не з нормативами комплексу ГПО, а з нормативами Єдиної спортивної кваліфікації. 31965 р. почали діяти об’єднані (міжвишівські) відділення спортивного вдосконалення за окремими видами спорту, які проводили систематичну та якісну роботу із студентами високої спортивної кваліфікації.

Отже, згідно з програмою 1963 р. завданням спортивної підготовки студентів підпорядковується вже не лише факультативний, а й основний курс, обов'язковий для всіх студентів. Програма, також передбачала підготовку молоді до самостійної роботи в якості суддів з видів спорту.

У програмі 1963 р. з'явилися й інші змістові новації. Зокрема, у ній вперше був уведений розділ 3 професійно-прикладної фізичної підготовки. Вона поділялася на професійно-прикладну (виробничу) та військово-прикладну. Професійно-прикладна фізична культура спрямовувалася на створення передумов для успішного оволодіння певними професіями, на оптимізацію професійної діяльності та іiі впливу на людину. Отже, професійно-прикладна фізична підготовка $з$ 1960-х рр. починає розглядатися як один із змістових напрямів радянської системи фізичного виховання студентів, який повинен був формувати прикладні знання, фізичні та спеціальні якості, уміння та навички, що закладали підвалини для успішної професійної діяльності.

У деяких вишах заняття 3 фізичної культури почали проводитися з урахуванням специфіки факультету. Наприклад, в Херсонському педагогічному інституті до навчальних планів з фізичної культури на другому курсі природничого факультету були введені заняття 3 народної греблі. Вони забезпечували підготовку студентів до проходження педагогічної практики зі збору флори і фауни на Дніпрі [8, с. 87].

У зв'язку з тим, що основний та факультативний курс фізичного виховання за своїм змістом складали єдине ціле, пов'язане з розвитком спортивних навичок, було скореговано структуру фізичного виховання. Протягом усього терміну навчання на неї відводилося по 140 год. на рік (по 4 год. щотижневих занять). При цьому, на першому та другому курсах планувалося 70 год. на рік обов'язкового курсу та 70 год. - факультативного. На решті курсів - 140 год. на рік факультативних занять. Окрім того, важливою новацією було уведення до навчальної програми диференційованих нормативів і оцінок: «незадовільно», «задовільно», «добре», «відмінно». У 1-4 семестрах як підсумкова атестація з фізичного виховання залишався залік [7, с. 6].

У 1975 р. Міністерство вищої і середньої спеціальної освіти СРСР затвердило нову програму «Фізичного виховання для ВНЗ». У ній зберігалася та набувала нового наповнення спортивна спрямованість змісту фізичного виховання студентів. Свідченням цього є те, що основну ії частину складав навчальний матеріал для відділення спортивного вдосконалення.

3 початку 1980-х рр. акцент у змісті фізичної підготовки молоді почав зміщуватися 3 вирішення спортивних завдань на забезпечення масового оздоровлення. Формальне закріплення цього процесу відбулося після введення в дію у 1987 р. комплексної програми 3 фізичного виховання для вишів. Оздоровлення в ній планувалося здійснювати шляхом послідовного наростання фізичних навантажень від молодших до старших курсів. Для того щоб забезпечити успішне формування рухових умінь і навичок через їх багаторазове повторення та вдосконалення, зміст вишівської програми пов'язувався із матеріалом програм загальноосвітніх, професійно-технічних та середньо-спеціальних навчальних закладів.

Оздоровче спрямування змісту фізичного виховання студентів вишів доповнювалося $\mathrm{i}$ більш глибокою освітньою підготовкою. Програмою передбачалося, що студенти мали 
засвоїти знання з основ теорії та методики організації фізичного виховання і спортивного тренування; бути готовими до пропагандистської роботи в галузі фізичної культури; бути організаторами, тренерами та спортивними суддями. Для того щоб посилити увагу студентів до освітнього складника до залікових вимог з фізичного виховання було внесено питання 3 методики використання засобів фізичної культури і спорту в побуті та професійній діяльності.

Оздоровчо-освітня спрямованість змісту фізичного виховання студентів вишів була збережена і в базовій програмі для вищих навчальних закладів, затвердженої Державним комітетом СРСР з народної освіти у 1989 р. У ній метою фізичного виховання проголошувалося формування фізичної культури студента і здатності реалізовувати їі у професійній, фізкультурно-спортивній діяльності, в побуті й сім'ї. Окрім того, головним змістом усіх розділів базової програми, окрім удосконалення рухової діяльності, було формування особистісної потреби у фізичному вдосконаленні та здоровому способі життя. Зберігалася у цій програмі і професійно-прикладна спрямованість фізичного виховання.

У програмах 1980-х рр. була збережена диференціація фізичного виховання за відділеннями: підготовчим, спеціальним, спортивного вдосконалення. Заняття у цих відділеннях проводилися за двома змістовими компонентами: теоретичним і практичним.

Незмінним залишалася i структура фізичного виховання у вищих навчальних закладах. Так, базовий курс реалізовувався у вищій школі протягом усього періоду навчання через два види занять: обов'язкові і факультативні. У навчальних планах вони мали такий обсяг: у перших чотирьох семестрах - по 2 год. обов'язкових та по 2 год. факультативних занять; у всіх наступних семестрах - по 4 год. факультативних занять на тиждень. У вищих педагогічних навчальних закладах фізичне виховання викладалося в такому обсязі на всіх спеціальностях.

Отже, здійснений аналіз дає підстави зробити такі висновки: основними носіями змісту та структури фізичного виховання студентів ВНЗ були навчальні плани і програми єдиного державного зразка. Оновлення програм та навчальних планів, які суттєво впливали на розвиток змісту та структури фізичного виховання, відбувалися у 1948, 1953, 1956, 1963, 1975, 1987 та 1989 pp. У програмах зміст фізичного виховання диференціювався за спрямуванням (загальний фізичний розвиток; спортивне вдосконалення; освітньо-оздоровча, професійно-прикладна фізична підготовка), компонентами (теоретичні знання, практичні вміння), рівнем підготовки студентів (підготовче, спеціальне, спортивне відділення). Протягом досліджуваного періоду основні зміни у змісті стосувалися його спрямування. До кінця 1940-х рр. пріоритетом був загальнофізичний розвиток студентів, 3 1950-х - до середини 1980-х рр. - спортивне вдосконалення, з 1987 по 1991 рр. - освітньо-оздоровча та професійно-прикладна фізична підготовка студентів. У структуру фізичного виховання студентів вищих навчальних закладів входили два види занять: обов'язковий та факультативний курси. Навчальним планом установлювався обсяг годин, який відводився на опрацювання цих курсів. Протягом досліджуваного періоду відбувалися певні коригування обсягу залежно від змін у змісті фізичного виховання.

Подальшого розроблення потребує дослідження особливостей диференціації змісту фізичного виховання студентів педагогічних ВНЗ за статевою ознакою.

\section{Література}

1. Положение и программы по физической культуре. - Москва, 1948. - 84 с. 2. ЦДАВО України, ф. 166, оп. 15, спр. 1121, 21 арк. 3. ЦДАВО України, ф. 166, оп. 15, спр. 1657, 264 арк. 4. ЦДАВО України, ф. 166, оп. 15, спр. 1857, 105 арк. 5. ЦДАВО України, ф. 
166, оп. 15, спр. 2609, 216 арк. 6. ЦДАВО України, ф.166, оп. 15, спр. 2610, 106 арк. 7. ЦДАВО України, ф. 166, оп. 15, спр. 3761, 218 арк. 8. ЦДАВО України, ф. 166, оп. 15, спр. 4637, 114 арк.

\section{ТЕКСТОТВОРЕННЯ МОЛОДШИХ ШКОЛЯРІВ ЯК ПРОБЛЕМА ПЕДАГОГІКИ І СУМІЖНИХ ГАЛУЗЕЙ НАУКОВИХ ЗНАНЬ}

Компаній О. В. Текстотворення молодших школярів як проблема педагогіки i суміжних галузей наукових знань.

У статті автор розглядає питання текстотворення шляхом аналізу понять «текстова діяльність», «текстова компетентність», «текстотворчі вміння», наводить їх пояснення.

Ключові слова: текстотворення, текстова діяльність, текстова компетентність, текстотворчі вміння, зв'язне мовлення.

Компаний Е. В. Тектообразование младших школьников как проблема педагогики и смежных областей наук.

В статье автор рассматривает вопрос текстообразования путем анализа понятий «текстовая деятельность», «текстовая компетентность», «текстобразующие умения», разъясняет их сущность.

Ключевые слова: тектообразование, текстовая деятельность, текстовая компетентность, текстообразовательные умения, связная речь.

Kompanii O. V. Text formation of junior school pupils as a problem of pedagogy and related fields of science.

In the article the author examines text formation by the analysis of the terms «text activity», «text competence», «text formation skills» and explains their essence.

Key words: text formation, text activity, text competence, text formation skills, coherent speech.

В умовах інформатизації сучасного суспільства освітня парадигма вимагає перегляду навчально-виховного процесу, головною метою якого $є$ виховання грамотної, продуктивно мислячої особистості, яка володіє системою знань, розвиненими комунікативними i творчими здібностями. Такий підхід націлює на оволодіння текстотворенням, що дозволяє будувати усні і письмові висловлювання (тексти) на уроках української мови. Важлива роль у розв'язанні названих завдань належить початковій ланці навчання, оскільки саме в цей період закладаються базові освітні компетентності, зокрема - текстотворча.

Значний інтерес науковців до проблеми текстотворення засвідчує їі важливість та актуальність. У психолого-педагогічній літературі розкриваються питання породження i розуміння тексту (Н. Болотнова, Н. Валгіна, В. Гальперін, М. Доблаєв, М. Жинкін, І. Зимня, О. Леонтьєв, 3. Тураєва та ін.); окреслюються основні методичні прийоми роботи 3 ним, встановлюється послідовність їх застосування (В. Капінос, Ф. Буслаєв, Є. Голобородько, О. Горошкіна, Н. Грипас, М. Львов, Г. Михайловська, М. Пентилюк, М. Плющ).

Проблема текстотворення перебуває в тісному взаємозв'язку із розвитком зв'язного мовлення, що дозволяє школярам вільно спілкуватися в навколишньому середовищі. 